Special Section on Transition Metal Catalyzed Synthesis of Medicinally Relevant Molecules

\title{
Delineating an alternate convergent synthesis of brexpiprazole: a novel use of commercial 6,7-dihydrobenzo[b]thiophen-4(5H)-one as precursor to an efficacious Buchwald-Hartwig amination step
}

\author{
A SRAVANTH KUMAR, SAI GIRIDHAR SARMA KANDANUR, SAIKAT SEN and \\ SRINIVAS ORUGANTI* \\ Centre for Process Research and Innovation, Dr. Reddy's Institute of Life Sciences, University of Hyderabad \\ Campus, Gachibowli, Hyderabad, Telangana 500 046, India \\ E-mail: soruganti@drils.org
}

MS received 26 March 2018; revised 26 April 2018; accepted 26 April 2018; published online 14 June 2018

\begin{abstract}
Brexpiprazole - an anti-psychotic drug approved for the treatment of schizophrenia - has been synthesized via an extremely concise and convergent route, which involves in essence two key $\mathrm{C}-\mathrm{N}$ bond formation (amination) steps that serve to link the piperazine core between the constituent benzo[b]thiophene and 7-butoxyquinolin-2(1H)-one fragments. The highlight of this synthesis is the first amination step, which was effected quite efficaciously by a novel palladium mediated Buchwald-Hartwig coupling between $N$ Boc-piperazine and the triflate ester of benzo $[b]$ thiophen-4-ol (conveniently prepared in three steps from commercially available 6,7-dihydrobenzo[b]thiophen-4(5H)-one). Indeed, even without an extensive screening of catalysts, ligands and reaction conditions, this amination step could be performed quite efficiently with merely 1 mol\% catalyst loading, which cleanly afforded in $87 \%$ overall yield 1 -(benzo[b]thiophen-4-yl)piperazine- the starting material for the second $\mathrm{C}-\mathrm{N}$ bond formation and the final step in the synthesis of Brexpiprazole.
\end{abstract}

Keywords. Schizophrenia; anti-psychotic drugs; brexpiprazole; Buchwald-Hartwig amination; heterocycles; benzo[b]thiophen-4-ol.

\section{Introduction}

\subsection{Background}

The USFDA approval of the atypical (or, 'second generation') anti-psychotic drug brexpiprazole 1(Rexulti®, Otsuka Pharmaceutical Company Ltd.) in 2015 strengthened a new way forward in the treatment of schizophrenia, a severe mental disorder that as of 2016, affects more than 21 million people worldwide. ${ }^{1,2}$ Most notably, $\mathbf{1}$ is a partial agonist of the dopamine receptor $\mathrm{D}_{2}$ and prior to its approval, the only $\mathrm{D}_{2}$ partial agonist that had reached the market with the approved indication of schizophrenia was its top-selling predecessor aripiprazole 2(Abilify®). ${ }^{\text {a }}$ Projected as a better tolerated variant, brexpiprazole 1 has been reported to have a lesser tendency than $\mathbf{2}$ to bring about $\mathrm{D}_{2}$ partial agonist induced adverse effects such as akathisia, insomnia, restlessness and nausea. ${ }^{1,3}$ In fact, the Thomson Reuters 2015 annual report named Rexulti ${ }^{\circledR}$ as one of the predicted blockbuster entrants and slated its annual sales to reach $\$ 1.353$ billion in $2019 .{ }^{4}$

From a structural perspective (and a viewpoint of retrosynthetic analysis as well), brexpiprazole $\mathbf{1}$ and aripiprazole $\mathbf{2}$ are broadly similar, and consist essentially of an $N$-arylpiperazine moiety joined by a $n$-butyl linker to a subunit derived from 7-hydroxyquinolinone 3. Unsurprisingly, the foregoing structural analysis also defines the two key retrosynthetic disconnections which are common to best known syntheses of $\mathbf{1}$ and $\mathbf{2}$ (Scheme 1). Thus, the most widely employed method of aripiprazole synthesis involves $N$-alkylation of 1-(2,3dichlorophenyl)piperazine 4 with 7-(4-halobutoxy)-3,4dihydroquinolinone 5; the latter in turn is obtained via etherification of 7-hydroxy-3,4-dihydroquinolinone 6 (Scheme 1). ${ }^{5}$ Likewise, a majority of the synthetic

\footnotetext{
*For correspondence

Electronic supplementary material: The online version of this article (https://doi.org/10.1007/s12039-018-1470-z) contains supplementary material, which is available to authorized users.
} 

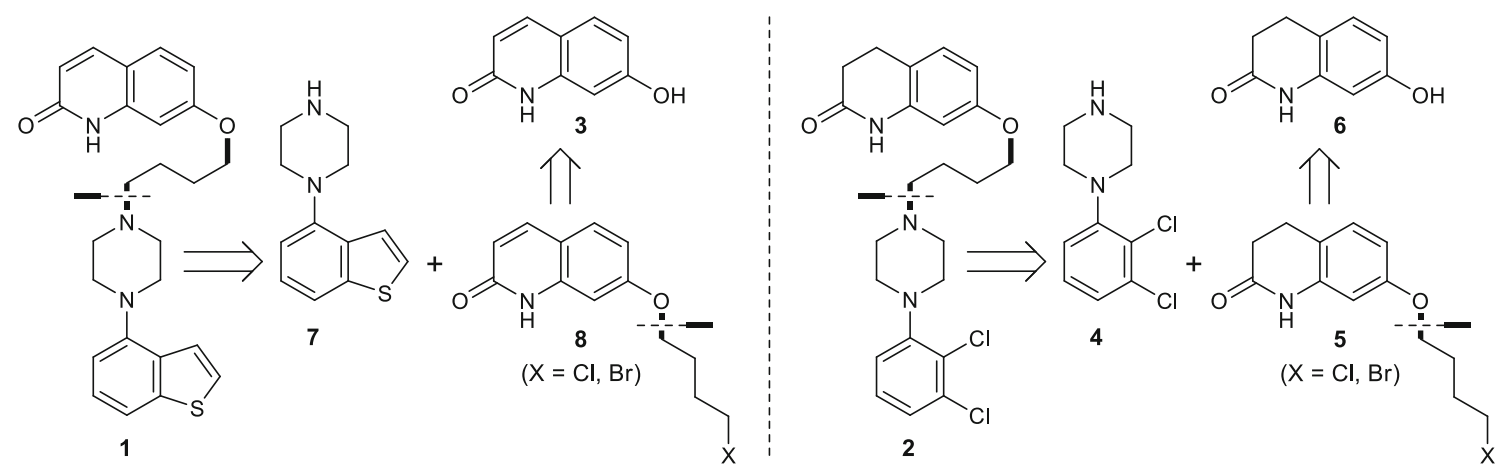

Scheme 1. Commonalities in the retrosynthetic bond disconnection strategies most widely adopted for brexpiprazole $\mathbf{1}$ and aripiprazole 2.

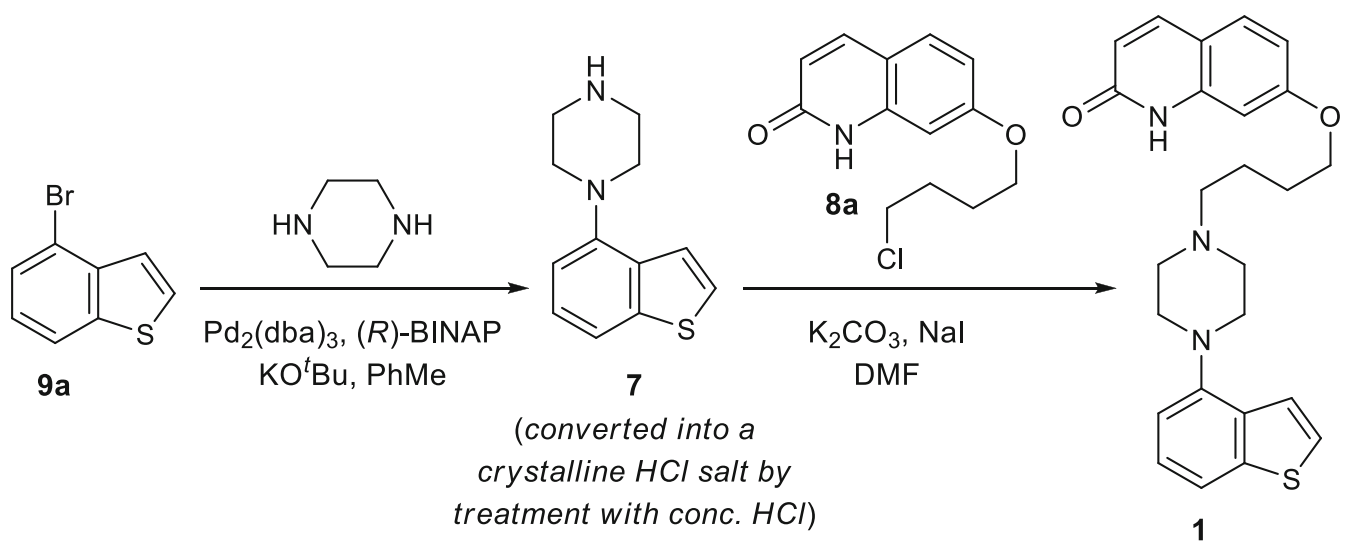

Scheme 2. Synthesis of the key intermediate 7 and its elaboration to 1 (Otsuka; WO 2006/112464 A1).

routes to 1 invariably involve reacting 1-(benzo $[b]$ thiophen-4-yl)piperazine 7 with 7-(4-halobutoxy)quinolinone $\mathbf{8}$ (prepared by etherification of $\mathbf{3}$ ). ${ }^{6}$ Given the well demonstrated (and predicted) efficiency of the $\mathrm{N}$-alkylation step, advances in commercial manufacturing of $\mathbf{1}$ have, needless to say, primarily targeted an efficacious acquisition of the tricyclic framework of $7 .^{7}$

For example, the first synthetic route to $\mathbf{1}$, as disclosed by the innovator in $2006,{ }^{8}$ employed a $\mathrm{Pd}_{2}(\mathrm{dba})_{3} /(R)$ BINAP catalyzed Buchwald-Hartwig coupling between 4-bromobenzo $[b]$-thiophene $9 \mathbf{a}$ and excess piperazine to obtain 7 as a yellow oil in 64\% yield after purification by silica gel column chromatography. The free base 7 , thus obtained, was characterized after conversion into its recrystallized hydrochloride salt; the latter was reacted with 7-(4-chlorobutoxy)-1H-quinolin-2-one 8a in presence of $\mathrm{K}_{2} \mathrm{CO}_{3}$ and $\mathrm{NaI}$ to furnish 1 (Scheme 2). As elaborated upon as a prelude to an improved strategy in a subsequent 2013 Otsuka patent, ${ }^{9}$ this original process to $\mathbf{1}$ is inherently inefficient at the $N$-arylation step; it suffers from the formation of a large number of by-products and inevitably requires careful chromatographic separation to obtain 7 in high purity. In Otsuka's second generation approach to brexpiprazole, a $\mathrm{Pd}(\mathrm{OAc})_{2}$ mediated Buchwald-Hartwig coupling between 4-chlorobenzo [b]-thiophene $\mathbf{9 b}$ and piperazine was utilized as means to obtain the key intermediate 7 (Scheme 3). Preparation of 9b involved two key steps: (a) elaboration of 2-carboxy-4-chlorobenzo[b] thiophene $\mathbf{1 1}$ from either 2,6-dichlorobenzaldehyde 10a or 2-chloro-6-fluorobenzaldehyde 10b by employing either rhodanine or thioglycolic acid as a one carbon synthon and an eventual source of a thiol functionality and (b) protodecarboxylation of $\mathbf{1 1}$ to $\mathbf{9 b}$ at temperatures in excess of $140{ }^{\circ} \mathrm{C}$. ${ }^{9,10}$ While application of specialized ligands (such as RuPhos and tri-tert-butylphosphonium tetraphenylborate) in the $\mathrm{Pd}(\mathrm{OAc})_{2}$ catalyzed $\mathrm{N}$ arylation of piperazine with $\mathbf{9 b}$ minimized unwanted reactions, it did not completely eliminate formation of such hard-to-separate diarylated impurities as $\mathbf{1 2}$ and 13.

A workaround solution to deal with the impurities encountered in Otsuka's preparation of $\mathbf{7}$ was provided in a recent communication by Xiangrui and co-workers (Scheme 4). ${ }^{11}$ Herein, the key $\mathrm{C}-\mathrm{N}$ bond formation en route to 7 was achieved at the outset of the synthesis by a controlled $S_{N}$ Ar reaction between $10 \mathrm{~b}$ and 1-Bocpiperazine to furnish 14 . Thereafter, the aldehyde 14 was converted into benzo[b]thiophene $\mathbf{1 7}$ in a down-stream process that closely followed Otsuka's synthesis of $\mathbf{9 b}$ 

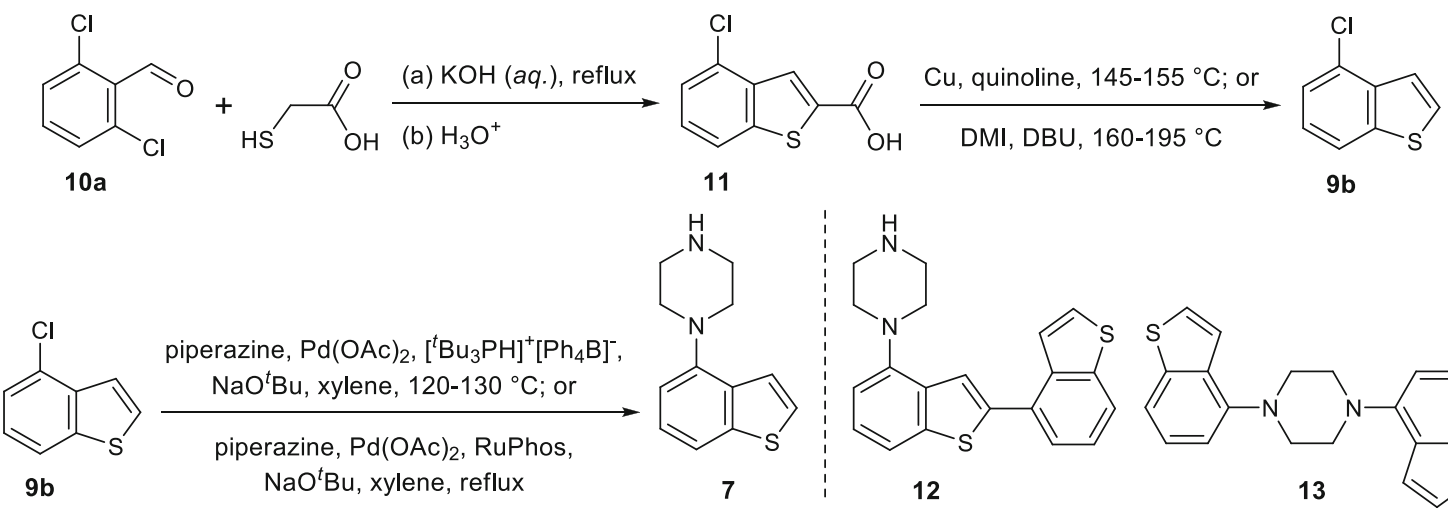
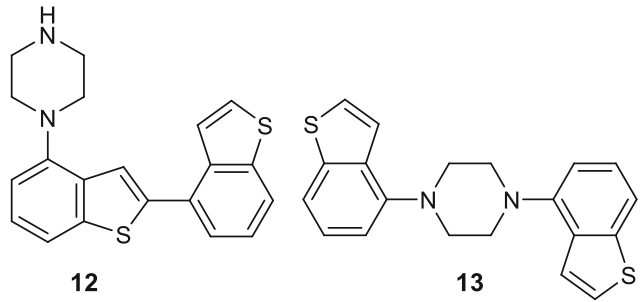

Scheme 3. An example of Otsuka's synthesis of $\mathbf{9 b}$ and its use in Buchwald-Hartwig coupling with piperazine to obtain 7 (Otsuka; WO 2013/015456 A1).

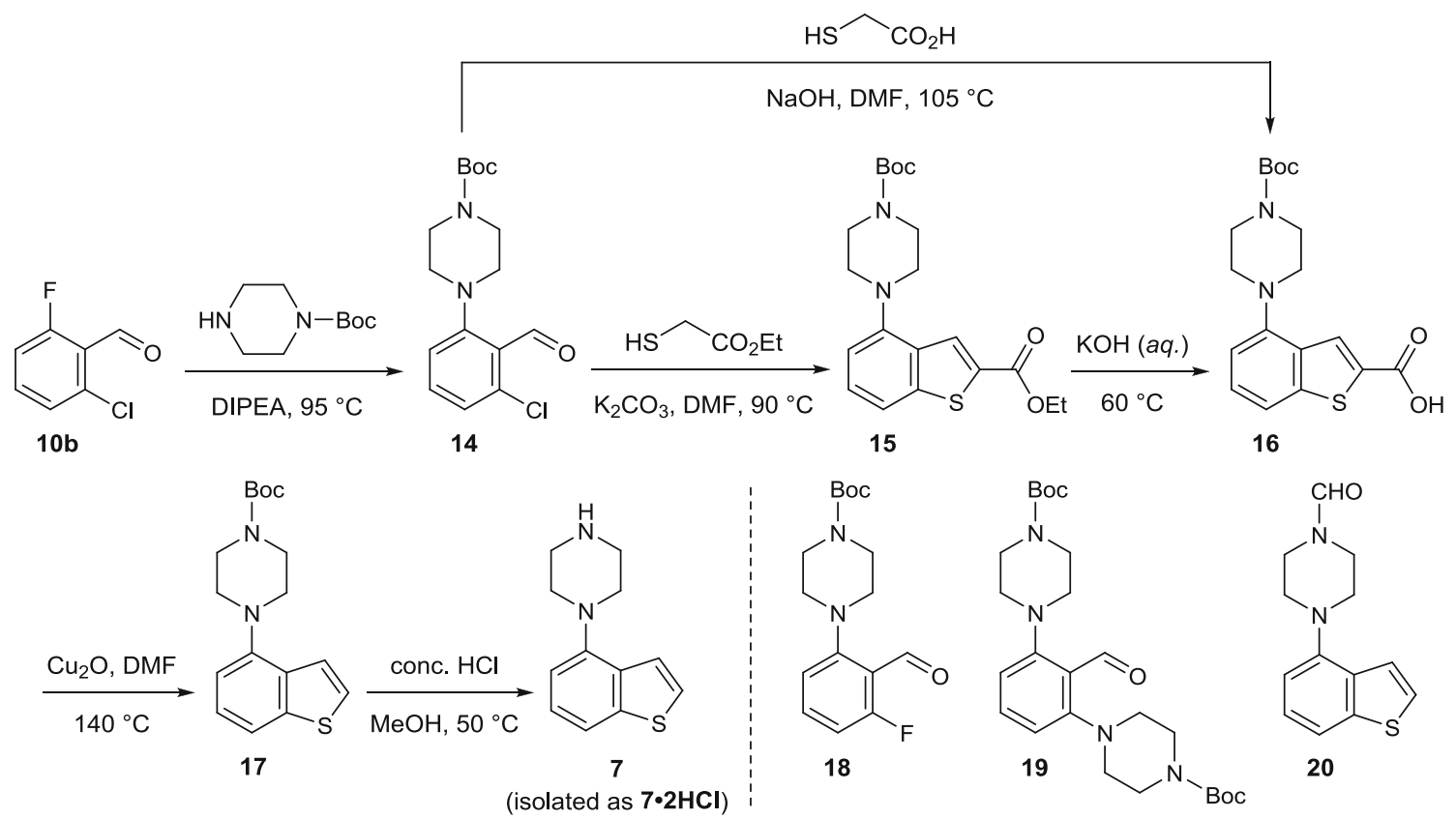

Scheme 4. Synthesis of $\mathbf{7 \cdot 2 H C l}$ from 2-chloro-6-fluorobenzaldehyde $\mathbf{1 0 b}$ as reported by Xiangrui and co-workers.

from 10b. Finally, removal of the $N$-Boc protection in $\mathbf{1 7}$ with concentrated $\mathrm{HCl}$ afforded 7 as a dihydrochloride salt. Despite providing an alternate amination strategy, Xiangrui's synthesis of $\mathbf{7}$ is nonetheless a linear one, and suffers from formation of impurities such as $\mathbf{1 8}$ and $\mathbf{1 9}$ [in the step $\mathbf{1 0 b} \rightarrow \mathbf{1 4}$ ] and $\mathbf{2 0}$ [in the step $\mathbf{1 6}$ $\rightarrow 17$, on account of the instability of the tert-butylcarboxylate moiety at the high temperatures $\left(\sim 140{ }^{\circ} \mathrm{C}\right)$ employed to effect decarboxylation in 16]. Against this background and in keeping with our on-going interest in investigating applications of transition metal catalysis in the synthesis of contemporary active pharmaceutical ingredients, ${ }^{12}$ we decided to re-design Otsuka's convergent synthesis of brexpiprazole $\mathbf{1}$, and delineate a highly concise route to the API by employing commercially available 6,7-dihydrobenzo[b]thiophen-4(5H)-one 21,
1-Boc-piperazine and the aripiprazole precursor 7-(4bromobutoxy)-3,4-dihydroquinolinone $\mathbf{5 b}$ as the only building blocks.

\subsection{Retrosynthetic analysis}

As shown in Scheme 5, our retrosynthetic analysis of $\mathbf{1}$ relied on two key $\mathrm{C}-\mathrm{N}$ bond formation steps, namely: (a) $\mathrm{N}$-alkylation of 7 with 7-(4-bromobutoxy)quinolinone $\mathbf{8 b}$, the latter being obtained by DDQ oxidation of 5b; and (b) Buchwald-Hartwig coupling of 1-Bocpiperazine with the triflate ester $\mathbf{2 3}$ of benzo $[b]$ thiophen4-ol 22, which in turn can be prepared via aromatization of 21. While commercially available, the bicyclic ketone 21 can also be easily prepared from thiophene in three steps, viz., Friedel-Crafts acylation with succinic 


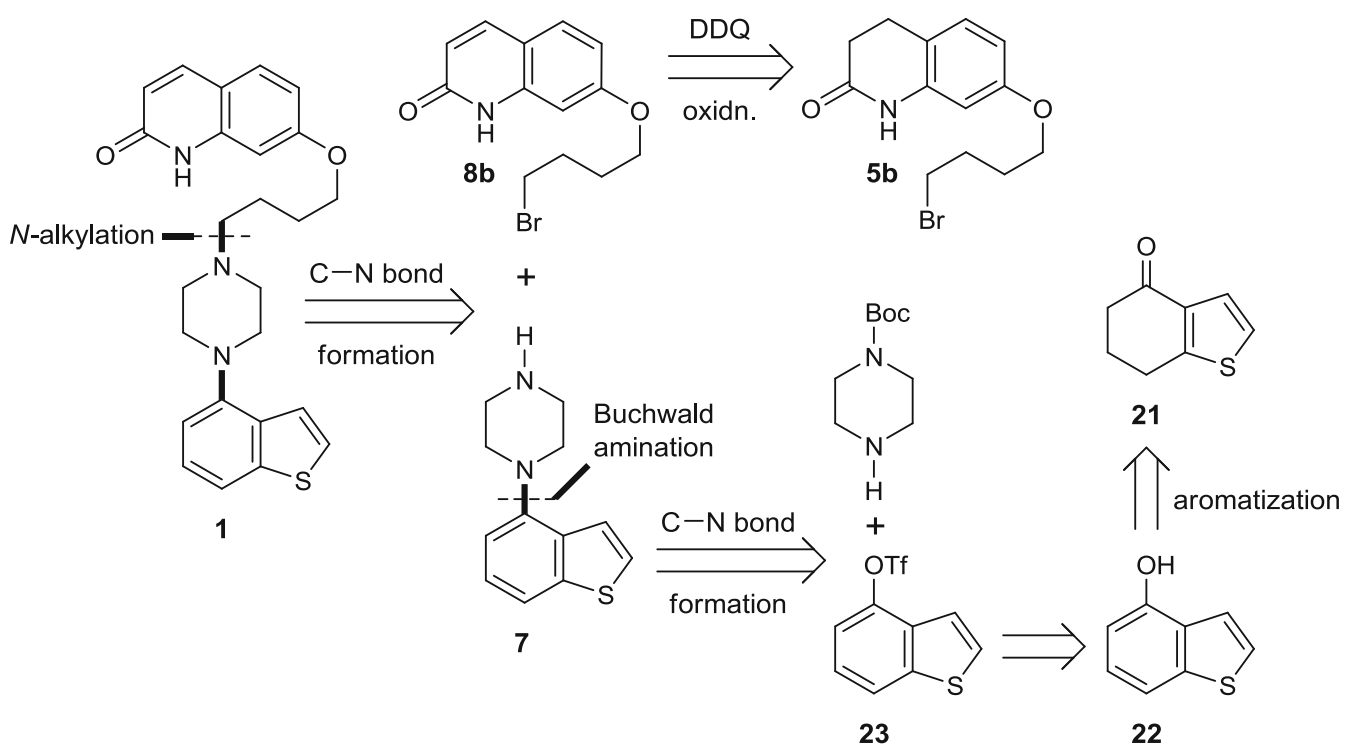

Scheme 5. Retrosynthetic analysis of $\mathbf{1}$ from 6,7-dihydrobenzo[b]thiophen-4(5H)-one 21, 1-Boc-piperazine and the aripiprazole precursor 7-(4-bromobutoxy)-3,4-dihydroquinolinone $\mathbf{5 b}$.

anhydride, Wolff-Kishner reduction of the $\gamma$-ketoacid intermediate and annulation via intramolecular FriedelCrafts acylation in the 4-(thiophen-2-yl)butanoic acid obtained. ${ }^{13}$

\section{Experimental}

\subsection{General information}

Reactions were carried out in oven-dried glassware under a positive pressure of nitrogen unless otherwise mentioned. Air-sensitive reagents and solutions were transferred via syringe and were introduced to the apparatus via rubber septa. ${ }^{1} \mathrm{H}$ and ${ }^{13} \mathrm{C}$ NMR spectra were recorded on a Varian 400 $\mathrm{MHz}$ spectrometer. Deuterated solvents for NMR spectroscopic analyses were used as received. Coupling constants are reported in Hz. All chemical shifts are quoted in ppm, relative to TMS, using the residual solvent peak as a reference standard. The following abbreviations are used to explain the multiplicities: $\mathrm{s}=$ singlet, $\mathrm{bs}=$ broad singlet, $\mathrm{d}=$ doublet, $\mathrm{dd}$ $=$ doublet of doublet $\mathrm{t}=$ triplet, $\mathrm{q}=$ quartet, $\mathrm{m}=$ multiplet, $\mathrm{br}=$ broad. Mass spectra were recorded on an Agilent 6430 triple quad LC/MS system. The purity of the compounds were determined by HPLC with a Waters Alliance e2695 separation module, equipped with a Waters 2998 photodiode array detector and analysed by Empower2 software. Reactions were monitored by thin-layer chromatography (TLC) performed on Merck TLC silica gel 60 F254 aluminum plates. Visualization was accomplished with either UV light, or by immersion in an ethanolic solution of phosphomolybdic acid (PMA), ninhydrin, or $\mathrm{KMnO} 4$, followed by heating with a heat gun for $15 \mathrm{~s}$. Dry toluene and THF were either distilled over sodium benzophenone ketyl, or procured commercially. Yields of $\mathbf{7 \cdot 2} \mathbf{H C l}$ were calculated on the basis of product assay determined by quantitative NMR (qNMR) with 1,3,5-trimethoxybenzene as an internal standard.

\subsection{Experimental procedures and spectral characterization}

2.2a Benzo[b]thiophen-4-ol (22): $\quad$ To a $100 \mathrm{~mL}$ twoneck round-bottom flask fitted with a magnetic stir bar and nitrogen inlet was charged 6,7-dihydrobenzo[ $b]$ thiophen4(5H)-one 21 (1.29 g, $8.48 \mathrm{mmol})$ in $20 \mathrm{~mL}$ dry THF and added $\mathrm{PhN}^{+} \mathrm{Me}_{3} \mathrm{Br}_{3}^{-}(3.18 \mathrm{~g}, 8.48 \mathrm{mmol})$ portion wise at $0{ }^{\circ} \mathrm{C}$. The resulting solution was stirred at $0{ }^{\circ} \mathrm{C}$ for $90 \mathrm{~min}$, warmed slowly to rt, and further stirred at $\mathrm{rt}$ for $30 \mathrm{~min}$. Upon consumption of starting material as indicated by TLC (as the ratio of product increases in the reaction mixture, the color of the reaction mixture changed from pale orange to light yellow), the reaction mixture was quenched with water and extracted with ethyl acetate $(3 \times 70 \mathrm{~mL})$. The organic layer was dried over anhydrous $\mathrm{Na}_{2} \mathrm{SO}_{4}$ and concentrated under reduced pressure to afford a musk colored solid (2.97 g).

The musk color solid obtained in the previous step was taken in DMF $(20 \mathrm{~mL})$ without any further purification into a $100 \mathrm{~mL}$ round bottom flask. $\mathrm{Li}_{2} \mathrm{CO}_{3}(2.16 \mathrm{~g}, 29.23 \mathrm{mmol})$ and $\mathrm{LiBr}(3.30 \mathrm{~g}, 38.00 \mathrm{mmol}$ ) were charged consecutively and resulting reaction mixture was heated to $150{ }^{\circ} \mathrm{C}$ for $5 \mathrm{~h}$. Upon consumption of starting material (as indicated by TLC), the reaction mixture was quenched with water and extracted with ethyl acetate $(3 \times 50 \mathrm{~mL})$. The organic layer was washed with brine solution, water, dried over anhydrous $\mathrm{Na}_{2} \mathrm{SO}_{4}$ and concentrated under reduced pressure to get the crude compound as a brownish solid. The crude compound was purified by column chromatography over $60-120$ mesh (5\% ethyl acetate/ hexane) to afford the title compound $\mathbf{2 2}$ as a white solid. Yield: $88 \%$ (1.13 g); ${ }^{1} \mathrm{H}$ NMR (400 MHz, 
$\left.\mathrm{CDCl}_{3}\right): \delta 7.50-7.43(\mathrm{~m}, 2 \mathrm{H}), 7.39-7.35(\mathrm{~m}, 1 \mathrm{H}), 7.20(\mathrm{t}$, $J=7.9 \mathrm{~Hz}, 1 \mathrm{H}), 6.72(\mathrm{dd}, J=7.7,0.6 \mathrm{~Hz}, 1 \mathrm{H}), 5.10$ $(\mathrm{s}, 1 \mathrm{H}) ;{ }^{13} \mathrm{C} \mathrm{NMR}\left(100 \mathrm{MHz}, \mathrm{CDCl}_{3}\right): \delta 150.71,141.86$, 129.23, 125.28, 125.07, 119.69, 115.24, 108.80; ESI (MS): $151[\mathrm{M}+\mathrm{H}]^{+}$; HPLC purity: 99.18\% [RT: $11.930 \mathrm{~min}$; UV detection at $220 \mathrm{~nm}$; Column: X-Terra RP 18, $150 \times 4.6 \mathrm{~mm}$, $5 \mu \mathrm{m}$ particle size; Mobile phase: A) $0.1 \%$ TFA in water B) Acetonitrile; T/\%B: 0/20, 3/20, 12/95, 23/95, 25/20, 30/20; Flow rate: $1.0 \mathrm{~mL} / \mathrm{min}$; Diluent: Acetonitrile:Water (80:20)]. ${ }^{1} \mathrm{H}$ NMR spectral data of $\mathbf{2 2}$ was found to be consistent with the values reported in Ref. ${ }^{14}$.

\section{2b Benzo[b]thiophen-4-yl trifluoromethanesulfon-} ate (23): Benzo[b]thiophen-4-ol (22) (500 mg, $3.33 \mathrm{mmol}$ ) was charged in a $100 \mathrm{~mL}$ two-neck round-bottom flask fitted with a magnetic stir bar, nitrogen inlet and dry $\mathrm{CH}_{2} \mathrm{Cl}_{2}(10 \mathrm{ml})$. To this reaction mixture was added triethylamine $(1.16 \mathrm{~mL}, 8.32 \mathrm{mmol})$ following which the contents were cooled to $0{ }^{\circ} \mathrm{C}$ and trifluoromethanesulfonic anhydride (0.61 mL, $3.66 \mathrm{mmol})$ was added carefully drop wise. The reaction was allowed to stir at $0{ }^{\circ} \mathrm{C}$ for $1 \mathrm{~h}$. Upon consumption of starting material (as indicated by TLC), the reaction mixture was quenched with saturated $\mathrm{NaHCO}_{3}$ solution. The organic layer was washed thoroughly with brine solution, water, dried over anhydrous $\mathrm{Na}_{2} \mathrm{SO}_{4}$ and concentrated under reduced pressure to afford the crude product. The crude compound was purified by column chromatography over 60-120 mesh ( $2 \%$ ethyl acetate/ hexane) to afford the $\mathbf{2 3}$ as colorless oil. Yield: $90 \%$ (846 mg); ${ }^{1} \mathrm{H}$ NMR (400 MHz, $\mathrm{CDCl}_{3}$ ): $\delta 7.88(\mathrm{~d}, J=7.9 \mathrm{~Hz}, 1 \mathrm{H}), 7.58(\mathrm{~d}, J=5.5 \mathrm{~Hz}, 1 \mathrm{H})$, $7.47(\mathrm{~d}, J=5.5 \mathrm{~Hz}, 1 \mathrm{H}), 7.39(\mathrm{t}, J=8.0 \mathrm{~Hz}, 1 \mathrm{H})$, $7.32(\mathrm{~d}, J=7.9 \mathrm{~Hz}, 1 \mathrm{H}) ;{ }^{13} \mathrm{C} \mathrm{NMR}\left(100 \mathrm{MHz}, \mathrm{CDCl}_{3}\right)$ : $\delta 144.04,142.53,132.63,128.91,124.74,122.69,119.25$, $118.73\left(\mathrm{q}, J_{C F}=319 \mathrm{~Hz}, \mathrm{CF}_{3}\right), 116.44$; ESI (MS): 281 [M-H] ${ }^{-}$; HPLC purity: 98.94\% [RT: $14.212 \mathrm{~min}$, UV detection at $225 \mathrm{~nm}$; Column: X-Terra RP 18, $150 \times 4.6 \mathrm{~mm}, 5 \mu \mathrm{m}$ particle size; Mobile phase: A) $0.1 \%$ TFA in water B) Acetonitrile; T/\%B: 0/20, 3/20, 12/95, 23/95, 25/20, 30/20; Flow rate: $1.0 \mathrm{~mL} / \mathrm{min}$; Diluent: Acetonitrile:Water (80:20)]. ${ }^{1} \mathrm{H}$ and ${ }^{13} \mathrm{C}$ NMR spectral data of $\mathbf{2 3}$ were found to be consistent with the values reported in Ref. ${ }^{15}$.

2.2c 1-(Benzo[b]thiophen-4-yl)piperazinedihydroch-

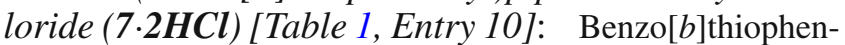
4-yl trifluoromethanesulfonate $23(2.0 \mathrm{~g}, 7.08 \mathrm{mmol})$ was charged in dry toluene $(20 \mathrm{~mL})$ into a $100 \mathrm{~mL}$ twoneck round-bottom flask fitted with a magnetic stir bar and argon inlet. To this reaction mixture, 1-Boc-piperazine $(1.97 \mathrm{~g}, 10.62 \mathrm{mmol}), \mathrm{Pd}_{2}(\mathrm{dba})_{3} \cdot \mathrm{CHCl}_{3}(0.73 \mathrm{~g}, 0.708 \mathrm{mmol}$; $10 \mathrm{~mol} \%)$, XPhos (0.50 g, $1.062 \mathrm{mmol} ; 15 \mathrm{~mol} \%)$ and $\mathrm{Cs}_{2} \mathrm{CO}_{3}(6.92 \mathrm{~g}, 21.24 \mathrm{mmol})$ were added consecutively under argon atmosphere. The reddish brown solution obtained was degassed with vacuum pump. The reaction was then heated to $100{ }^{\circ} \mathrm{C}$ for $8 \mathrm{~h}$ under argon atmosphere. Upon completion of the starting material (as indicated by mass and TLC analysis) the reaction mixture was filtered over a short pad of Celite and the filtrate was evaporated under reduced pressure.
The residue obtained was passed through a short pad of silica gel (60-120 mesh) using 4\% ethyl acetate/hexane to remove metal salts, inorganic matter and excess 1-Boc piperazine.

The partially purified product 17, (NOTE: Analytical data obtained for a sample of $\mathbf{1 7}$ purified by column chromatography: ${ }^{1} \mathrm{H}$ NMR $\left(400 \mathrm{MHz}, \mathrm{CDCl}_{3}\right): \delta 7.57(\mathrm{~d}, J=7.9 \mathrm{~Hz}$, 1H), 7.41 (brs, 2H), $7.28(\mathrm{t}, J=7.7 \mathrm{~Hz}, 1 \mathrm{H}), 6.88(\mathrm{~d}$, $J=7.2 \mathrm{~Hz}, 1 \mathrm{H}), 3.66$ (brs, 4H), 3.10 (brs, 4H), 1.50 (s, $9 \mathrm{H}) ;{ }^{13} \mathrm{CNMR}\left(100 \mathrm{MHz}, \mathrm{CDCl}_{3}\right): \delta 154.83,148.22,141.17$, 134.17, 125.29, 124.96, 121.61, 117.40, 112.40, 79.84, 52.11, 28.46; ESI (MS): $319.1[\mathrm{M}+\mathrm{H}]{ }^{+},{ }^{1} \mathrm{H}$ and ${ }^{13} \mathrm{C}$ NMR spectral data of $\mathbf{1 7}$ were found to be consistent with the values reported in Ref. ${ }^{11}$ ), thus obtained was dissolved in $25 \mathrm{~mL}$ THF and taken in a $100 \mathrm{~mL}$ round bottom flask. $25 \mathrm{~mL}$ of $6 \mathrm{~N} \mathrm{HCl}$ was charged at $0{ }^{\circ} \mathrm{C}$ and the reaction mixture was stirred overnight at rt. Upon completion of the starting material (as indicated by TLC), THF was evaporated under reduced pressure. The reaction mixture was diluted with $30 \mathrm{~mL} 6 \mathrm{~N}$ $\mathrm{HCl}$, and washed with dichloromethane $(3 \times 20 \mathrm{~mL})$. The washed aqueous layer was evaporated under reduced pressure at $55^{\circ} \mathrm{C}$ to furnish the required product 1 -(benzo $[b]$ thiophen4-yl) piperazine dihydrochloride $(\mathbf{7 \cdot 2 H C l})$ as an off-white solid. $61 \%$ over two steps by q-NMR $(1.37 \mathrm{~g}) ;{ }^{1} \mathrm{H}$ NMR $\left(400 \mathrm{MHz}, \mathrm{DMSO}-d_{6}\right): \delta 9.60$ (brs, $2 \mathrm{H}$ ), 8.68 (brs, $1 \mathrm{H}$ ), 7.71 (brs, $1 \mathrm{H}), 7.65$ (d, $J=7.2 \mathrm{~Hz}, 1 \mathrm{H}), 7.49$ (brs, $1 \mathrm{H}), 7.27$ (brs, $1 \mathrm{H}), 6.92(\mathrm{~d}, J=5.9 \mathrm{~Hz}, 1 \mathrm{H}), 3.27(\mathrm{~s}, 8 \mathrm{H}) ;{ }^{13} \mathrm{C} \mathrm{NMR}$ (100 MHz, DMSO- $\left.d_{6}\right): \delta 147.41,141.04,133.84,126.96$, 125.52, 122.36, 118.15, 112.98, 49.00, 43.53; ESI (MS): 219 $[\mathrm{M}+\mathrm{H}]^{+}$; HPLC purity: $99.20 \%$ [RT: $8.623 \mathrm{~min}$; UV detection at $220 \mathrm{~nm}$; Column: X Bridge C-18, $150 \times 4.6 \mathrm{~mm}$, $5 \mu \mathrm{m}$ particle size; Mobile phase: A) $0.1 \%$ TFA in water, B) Acetonitrile; T/\%B: 0/10, 3/10, 12/95, 23/95, 25/10, 30/10; Flow rate: $1.0 \mathrm{~mL} / \mathrm{min}$; Diluent: Acetonitrile:Water (80:20)]. ${ }^{1} \mathrm{H}$ and ${ }^{13} \mathrm{C}$ NMR spectral data of $\mathbf{7 . 2} \mathbf{H C l}$ were found to be consistent with the values reported in Ref. ${ }^{11}$.

\section{2d 1-(Benzo[b]thiophen-4-yl)piperazinedihydroch-} loride $(\mathbf{7 \cdot 2 H C l}$ [Table 1, Entry 13]: To a $50 \mathrm{~mL}$ twoneck round-bottom flask fitted with a magnetic stir bar and argon inlet, benzo[ $b]$ thiophen-4-yl trifluoromethanesulfonate $23(1.0 \mathrm{~g}, 3.54 \mathrm{mmol})$ was charged in dry toluene $(10 \mathrm{~mL})$. 1-Boc-piperazine $(0.98 \mathrm{~g}, 5.31 \mathrm{mmol}), \mathrm{Pd}_{2}(\mathrm{dba})_{3} \cdot \mathrm{CHCl}_{3}$ (0.036 g, $0.035 \mathrm{mmol} ; 1 \mathrm{~mol} \%)$, XPhos (0.05 g, $0.106 \mathrm{mmol}$; $3 \mathrm{~mol} \%)$ and $\mathrm{Cs}_{2} \mathrm{CO}_{3}(3.45 \mathrm{~g}, 10.62 \mathrm{mmol})$ were added consecutively to the reaction mixture under argon atmosphere. The reaction mixture was degassed with vacuum pump and then heated to $100{ }^{\circ} \mathrm{C}$ for $8 \mathrm{~h}$ under argon atmosphere. Upon completion of the starting material (as indicated by mass and TLC analysis) the reaction mixture was filtered over a short pad of Celite and the filtrate was evaporated under reduced pressure. The residue obtained was passed through a short pad of silica gel (60-120 mesh) using 4\% ethyl acetate/hexane as solvent system to remove metal salts, inorganic matter and excess 1-Boc-piperazine.

The partially purified product $\mathbf{1 7}$ thus obtained was dissolved in $15 \mathrm{~mL}$ of THF and taken in a $100 \mathrm{~mL}$ round bottom flask. $15 \mathrm{~mL}$ of $6 \mathrm{~N} \mathrm{HCl}$ was charged at $0{ }^{\circ} \mathrm{C}$ and 
Table 1. Buchwald-Hartwig coupling of the triflate $\mathbf{2 3}$ and 1-Boc-piperazine.

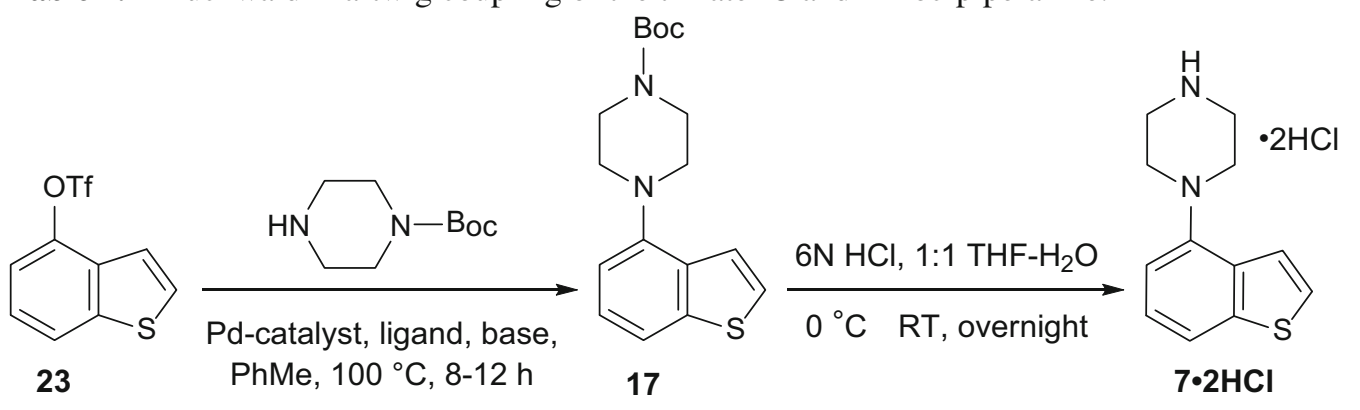

\begin{tabular}{|c|c|c|c|c|}
\hline Entry & Catalyst (loading) & Ligand (loading) & Base & Yield (\%) of $7 \cdot 2 \mathrm{HCl}$ (over two steps from 23$)^{\mathrm{a}}$ \\
\hline 1 & $\mathrm{Pd}(\mathrm{OAc})_{2}(20 \mathrm{~mol} \%)$ & CyJohnPhos (20 mol\%) & $\mathrm{NaO}^{t} \mathrm{Bu}$ & - \\
\hline 2 & $\mathrm{Pd}(\mathrm{OAc})_{2}(10 \mathrm{~mol} \%)$ & $\operatorname{tri}(o$-tolyl)phosphine $(15 \mathrm{~mol} \%)$ & $\mathrm{NaO}^{t} \mathrm{Bu}$ & Trace \\
\hline 3 & $\mathrm{Pd}(\mathrm{OAc})_{2}(10 \mathrm{~mol} \%)$ & $\operatorname{tri}(o$-tolyl)phosphine $(15 \mathrm{~mol} \%)$ & $\mathrm{Cs}_{2} \mathrm{CO}_{3}$ & - \\
\hline 4 & $\mathrm{Pd}(\mathrm{OAc})_{2}(10 \mathrm{~mol} \%)$ & XPhos $(15 \mathrm{~mol} \%)$ & $\mathrm{Cs}_{2} \mathrm{CO}_{3}$ & 70 \\
\hline 5 & $\mathrm{Pd}\left(\mathrm{PPh}_{3}\right)_{4}(10 \mathrm{~mol} \%)$ & XPhos (15 mol\%) & $\mathrm{Cs}_{2} \mathrm{CO}_{3}$ & 10 \\
\hline 6 & $\mathrm{Pd}\left(\mathrm{PPh}_{3}\right)_{2} \mathrm{Cl}_{2}(10 \mathrm{~mol} \%)$ & XPhos (15 mol\%) & $\mathrm{Cs}_{2} \mathrm{CO}_{3}$ & 64 \\
\hline 7 & $\mathrm{Pd}_{2}(\mathrm{dba})_{3} \cdot \mathrm{CHCl}_{3}(10 \mathrm{~mol} \%)$ & XPhos (15 mol\%) & $\mathrm{Cs}_{2} \mathrm{CO}_{3}$ & 78 \\
\hline 8 & $\mathrm{Pd}_{2}(\mathrm{dba})_{3} \cdot \mathrm{CHCl}_{3}(10 \mathrm{~mol} \%)$ & tri $(o$-tolyl)phosphine $(15 \mathrm{~mol} \%)$ & $\mathrm{Cs}_{2} \mathrm{CO}_{3}$ & 68 \\
\hline 9 & $\mathrm{Pd}_{2}(\mathrm{dba})_{3} \cdot \mathrm{CHCl}_{3}(10 \mathrm{~mol} \%)$ & CyJohnPhos (15 mol\%) & $\mathrm{Cs}_{2} \mathrm{CO}_{3}$ & 25 \\
\hline 10 & $\mathrm{Pd}_{2}(\mathrm{dba})_{3} \cdot \mathrm{CHCl}_{3}(10 \mathrm{~mol} \%)$ & XPhos (15 mol\%) & $\mathrm{Cs}_{2} \mathrm{CO}_{3}$ & 61 \\
\hline 11 & $\mathrm{Pd}_{2}(\mathrm{dba})_{3} \cdot \mathrm{CHCl}_{3}(3 \mathrm{~mol} \%)$ & XPhos (6 mol\%) & $\mathrm{Cs}_{2} \mathrm{CO}_{3}$ & 66 \\
\hline 12 & $\mathrm{Pd}_{2}(\mathrm{dba})_{3} \cdot \mathrm{CHCl}_{3}(1 \mathrm{~mol} \%)$ & XPhos (3 mol\%) & $\mathrm{Cs}_{2} \mathrm{CO}_{3}$ & 96 \\
\hline 13 & $\mathrm{Pd}_{2}(\mathrm{dba})_{3} \cdot \mathrm{CHCl}_{3}(1 \mathrm{~mol} \%)$ & XPhos (3 mol\%) & $\mathrm{Cs}_{2} \mathrm{CO}_{3}$ & 87 \\
\hline
\end{tabular}

Reaction Conditions: All reactions were performed at $100^{\circ} \mathrm{C}$ in dry toluene $(4 \mathrm{~mL}$ for Entries $1-9,11$ and 12) with 1.0 mole equiv. of triflate 23, 1.5 mole equiv. of 1-Boc-piperazine and 3.0 mole equiv. of the base. Entries 1-9, 11 and 12 were performed with $200 \mathrm{mg}$ of 23. Entries 10 and 13 were performed with $2 \mathrm{~g}$ and $1 \mathrm{~g}$ of 23, respectively ( $c f$. Sections $2.2 \mathrm{c}$ and $2.2 \mathrm{~d}$ for details).

${ }^{a}$ For Entries 1-9, yields were calculated based simply on the weight of the product isolated, assuming the sample to be entirely $7 \cdot 2 \mathrm{HCl}$. For Entries 10-13, yields of $\mathbf{7 \cdot 2} \mathbf{H C l}$ were calculated on basis of the assay of the isolated product as determined by quantitative NMR (qNMR) with 1,3,5-trimethoxybenzene as an internal standard ( $c f$. Sections $2.2 \mathrm{c}$ and 2.2d for details).

the contents were stirred overnight at rt. Upon completion of the starting material (indicated by TLC), THF was evaporated under reduced pressure. The reaction mixture was diluted with $15 \mathrm{~mL} 6 \mathrm{~N} \mathrm{HCl}$ and washed with dichloromethane $(3 \times 20 \mathrm{~mL})$. The washed aqueous layer was evaporated under reduced pressure at $55{ }^{\circ} \mathrm{C}$ to furnish an off-white solid which was subsequently washed with diethyl ether to afford required product 1-(benzo[ $b]$ thiophen-4-yl) piperazine dihydrochloride $(\mathbf{7 . 2 H C l})$ as an off white solid. Yield: $87 \%$ over two steps by q-NMR (919 mg,); HPLC purity: 98.73\% [RT: $8.645 \mathrm{~min}$; UV detection at $220 \mathrm{~nm}$; matches with the RT of Table 1, Entry 10 obtained under the given HPLC conditions; Column: X-Terra RP $18,150 \times 4.6 \mathrm{~mm}, 5 \mu \mathrm{m}$ particle size; Mobile phase: A) $0.1 \%$ TFA in water B) Acetonitrile; T/\%B: 0/20, 3/20, 12/95, 23/95, 25/20, 30/20; Flow rate: $1.0 \mathrm{~mL} / \mathrm{min}$; Diluent: Acetonitrile:Water (80:20)].

\section{2e 7-(4-Bromobutoxy)quinolin-2-(1H)-one $(8 \boldsymbol{b})$ :}

To a $500 \mathrm{~mL}$ two-neck round-bottom flask fitted with a magnetic stir bar and argon inlet was charged 7-[4-bromobutoxy]3,4-dihydro-2(1H)-quinolinone $\mathbf{5 b}(10 \mathrm{~g}, 0.033 \mathrm{~mol})$ in THF $(200 \mathrm{~mL})$. To the aforementioned mixture 2,3-dichloro-5,6dicyano-1,4-benzoquinone (30.4 g, $0.13 \mathrm{~mol}$ ) was added and the contents were stirred at rt until the completion of the reaction. Upon the consumption of starting material (as indicated by TLC), THF was evaporated under reduced pressure. The residual product obtained was washed with water $(200 \mathrm{~mL})$ and extracted with ethyl acetate $(3 \times 100 \mathrm{~mL})$. The organic layer was washed with brine, dried over anhydrous $\mathrm{Na}_{2} \mathrm{SO}_{4}$, and concentrated under reduced pressure to furnish the crude product. The crude product was purified by column chromatography using Ethyl acetate and $n$-Hexane as solvent system to afford the title compound $\mathbf{8 b}$. Yield: $98.99 \%$ (9.8 g); ${ }^{1} \mathrm{H}$ NMR $\left(400 \mathrm{MHz}\right.$, DMSO- $\left.d_{6}\right) \quad \delta 11.57(\mathrm{~s}, 1 \mathrm{H}), 7.77(\mathrm{~d}$, $J=9.4 \mathrm{~Hz}, 1 \mathrm{H}), 7.53(\mathrm{~d}, J=9.4 \mathrm{~Hz}, 1 \mathrm{H}), 6.83-6.69(\mathrm{~m}$, $2 \mathrm{H}), 6.27(\mathrm{~d}, J=9.6 \mathrm{~Hz}, 1 \mathrm{H}), 4.02(\mathrm{t}, J=6.1 \mathrm{~Hz}, 2 \mathrm{H}), 3.59$ (t, $J=6.6 \mathrm{~Hz}, 2 \mathrm{H}), 2.03-1.89(\mathrm{~m}, 2 \mathrm{H}), 1.89-1.74(\mathrm{~m}, 2 \mathrm{H})$; ${ }^{13} \mathrm{C}$ NMR (100 MHz, DMSO- $\left.d_{6}\right): \delta 162.67,160.72,141.05$, 140.44, 129.69, 118.97, 113.77, 111.19, 99.05, 67.28, 35.26, 29.46, 27.74; ESI (MS): 296 [M+H] ${ }^{+}$; HPLC purity: $99.26 \%$ [RT: $11.545 \mathrm{~min}$; UV detection at $210 \mathrm{~nm}$; Column: X Bridge C-18, $150 \times 4.6 \mathrm{~mm}, 5 \mu \mathrm{m}$ particle size; Mobile phase: A) $0.1 \%$ TFA in water, B) Acetonitrile; T/\%B: 0/10, 3/10, 15/95, 23/95, 25/10, 30/10; Flow rate: $1.0 \mathrm{~mL} / \mathrm{min}$; Diluent: Acetonitrile:Water (80:20)]. ${ }^{1} \mathrm{H}$ NMR spectral data of $\mathbf{8 b}$ was found to be consistent with the values reported in Ref. ${ }^{16}$. 


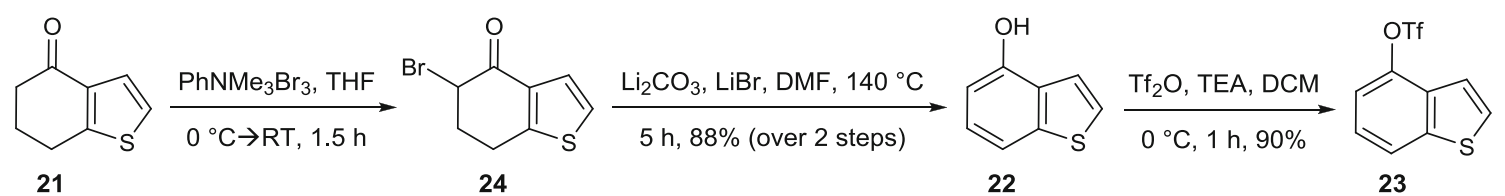

Scheme 6. Synthesis of the Buchwald-Hartwig arylation partner 23.

2.2f Brexpiprazole (1): 1-(Benzo[b]thiophen-4-yl) piperazinedihydrochloride (7.2HCl) $(282 \mathrm{mg}, 0.97 \mathrm{mmol})$ in dry DMF was taken in a $100 \mathrm{~mL}$ two-neck round-bottom flask fitted with a magnetic stir bar and argon inlet. To this reaction mixture, $\mathrm{K}_{2} \mathrm{CO}_{3}(488 \mathrm{mg}, 3.53 \mathrm{mmol}$ ) was added and the reaction was allowed to stir at $\mathrm{rt}$ for $30 \mathrm{~min}$. One mole equivalent of KI (167 mg, $1.01 \mathrm{mmol}$ ) and 7-(4-bromobutoxy)quinolin2(1H)-one $8 \mathbf{b}$ (300 mg, $1.01 \mathrm{mmol}$ ) were added consecutively. The contents were heated at $100{ }^{\circ} \mathrm{C}$ for $4 \mathrm{~h}$. Upon complete consumption of starting material (as indicated by TLC), the reaction mixture was cooled to $0{ }^{\circ} \mathrm{C}$, then $5 \mathrm{~mL}$ of water was added and stirred for $30 \mathrm{~min}$. The resultant precipitate (off-white solid) observed was filtered using sintered funnel, redissolved in a mixture of $\mathrm{MeOH}$ and $\mathrm{CH}_{2} \mathrm{Cl}_{2}$ and subjected to column chromatography (100-200 mesh) using $3 \% \mathrm{MeOH}$ in $\mathrm{CH}_{2} \mathrm{Cl}_{2}$ as solvent system to furnish the pure product Brexpiprazole 1 as a white solid. Yield: $85 \%$ (357 mg); ${ }^{1} \mathrm{H}$ NMR $\left(400 \mathrm{MHz}, \mathrm{DMSO}-d_{6}\right): \delta 11.60(\mathrm{~s}, 1 \mathrm{H}), 7.79(\mathrm{~d}, J=9.4 \mathrm{~Hz}$, $1 \mathrm{H}), 7.67(\mathrm{~d}, J=5.5 \mathrm{~Hz}, 1 \mathrm{H}), 7.59(\mathrm{~d}, J=8.1 \mathrm{~Hz}, 1 \mathrm{H})$, $7.54(\mathrm{~d}, J=9.0 \mathrm{~Hz}, 1 \mathrm{H}), 7.37(\mathrm{~d}, J=5.7 \mathrm{~Hz}, 1 \mathrm{H}), 7.25(\mathrm{t}$, $J=7.9 \mathrm{~Hz}, 1 \mathrm{H}), 6.85(\mathrm{~d}, J=7.7 \mathrm{~Hz}, 1 \mathrm{H}), 6.82-6.73(\mathrm{~m}$, $2 \mathrm{H}), 6.28(\mathrm{~d}, J=9.4 \mathrm{~Hz}, 1 \mathrm{H}), 4.03(\mathrm{t}, J=6.4 \mathrm{~Hz}, 2 \mathrm{H}), 3.04$ (brs, 4H), 2.62 (brs, 4H), 2.44 (t, $J=6.9 \mathrm{~Hz}, 2 \mathrm{H}), 1.84-1.70$ (m, 2H), 1.70-1.53 (m, 2H); ${ }^{13} \mathrm{C}$ NMR (100 MHz, DMSO$\left.d_{6}\right): \delta 162.73,160.89,148.62,141.09,140.85,140.49,133.80$, $129.69,126.28,125.53,122.33,118.89,117.11,113.72$, $112.47,111.32,99.03,68.04,57.74,53.36,52.05,26.98$, 23.06; ESI (MS): $434[\mathrm{M}+\mathrm{H}]^{+}$; HPLC purity: $97.97 \%$ [RT: 10.504 min; UV detection at $215 \mathrm{~nm}$; Column: X-Terra RP $18,150 \times 4.6 \mathrm{~mm}, 5 \mu \mathrm{m}$ particle size; Mobile phase: A) $0.1 \%$ TFA in water B) Acetonitrile; T/\% B: 0/20, 3/20, 12/95, 23/95, 25/20, 30/20; Flow rate: $1.0 \mathrm{~mL} / \mathrm{min}$; Diluent: Acetonitrile:Water (80:20)]. ${ }^{1} \mathrm{H}$ NMR spectral data of $\mathbf{1}$ was found to be consistent with the values reported in Ref. ${ }^{9}$.

\section{Results and Discussion}

As already alluded to, the Buchwald-Hartwig arylation partner $\mathbf{2 3}$ was conveniently prepared from $\mathbf{2 1}$ in three steps via the intermediacy of the phenol $\mathbf{2 2}$ (Scheme 6). Thus, following a known procedure, ${ }^{14}$ the ketone 21 was treated with trimethylphenylammonium tribromide in order to mono-brominate selectively the C-5 position and obtain 24, which was carried forward after work-up to the next step without any further purification. While the $\alpha$-bromo derivative $\mathbf{2 4}$ could also be obtained with molecular bromine in $\mathrm{CCl}_{4},{ }^{17}$ the product obtained was invariably contaminated with a significant amount of 2,5-dibromo-6,7-dihydrobenzo[ $b]$ thiophen$4(5 H)$-one 25. ${ }^{18}$ Indeed, even on a $500 \mathrm{mg}$ scale, bromination of 21 with $\mathrm{Br}_{2}$ would at times result in the formation of nearly an equal amount of $\mathbf{2 5}$ as the desired product 24.

When heated at $150{ }^{\circ} \mathrm{C}$ in DMF with a mixture of $\mathrm{Li}_{2} \mathrm{CO}_{3}$ and $\mathrm{LiBr}$, the crude $\alpha$-bromoketone 24 underwent a tandem dehydrobromination-aromatization and cleanly furnished the phenol 22 in nearly $88 \%$ yield. ${ }^{14}$ Esterification of $\mathbf{2 2}$ with triflic anhydride under basic conditions ${ }^{15}$ afforded the triflate $\mathbf{2 3}$ that was then subjected to a palladium catalyzed Buchwald-Hartwig amination with 1-Boc-piperazine. Since the use of $\mathbf{2 3}$ as an $\mathrm{N}$-arylation partner was found to be unprecedented in literature, a series of catalyst, ligand and base screening experiments were performed to arrive at the best possible reaction conditions for effecting the coupling of 1-Boc-piperazine and 23 (Table 1).

Thus, based on reaction conditions reported for Buchwald-Hartwig amination of various aryl triflates with $N$-protected piperazines, our first attempt at arylating 1-Boc-piperazine with $\mathbf{2 3}$ was carried out by employing $\mathrm{Pd}(\mathrm{OAc})_{2}$ as the catalyst, CyJohnPhos as the ligand and $\mathrm{NaO}^{t} \mathrm{Bu}$ as the base. However, even upon increasing the catalyst and ligand loading to $20 \mathrm{~mol} \%$, no evidence for formation of the desired product could be discerned (Table 1, Entry 1); rather, the only observable reaction in most of these attempts was a gradual hydrolysis of $\mathbf{2 3}$ over time. By replacing CyJohnPhos with tri( $o$-tolyl)phosphine, we were able to detect traces of the desired product 17 in the crude reaction mixture by mass analysis (Table 1, Entry 2). However, hydrolysis of 23 still prevailed, prompting us to replace with $\mathrm{Na}^{t} \mathrm{OBu}$ with $\mathrm{Cs}_{2} \mathrm{CO}_{3}$ as a base for subsequent screening experiments. Indeed, while a milieu of $\mathrm{Pd}(\mathrm{OAc})_{2},(o \text {-tol })_{3} \mathrm{P}$ and $\mathrm{Cs}_{2} \mathrm{CO}_{3}$ failed to promote the desired BuchwaldHartwig coupling, no evidence for triflate hydrolysis was observed even after allowing the reaction mixture to be heated at $100{ }^{\circ} \mathrm{C}$ for $12 \mathrm{~h}$ (Table 1, Entry 3). Much to our delight, we were eventually successful in realizing the coveted $\mathrm{N}$-arylation by employing XPhos as the ligand, and the key intermediate $\mathbf{7 . 2 H C l}$ could be isolated in $70 \%$ yield (over two steps) after $N$-Boc deprotection in the Buchwald product 17 (Table 1, Entry 4). 


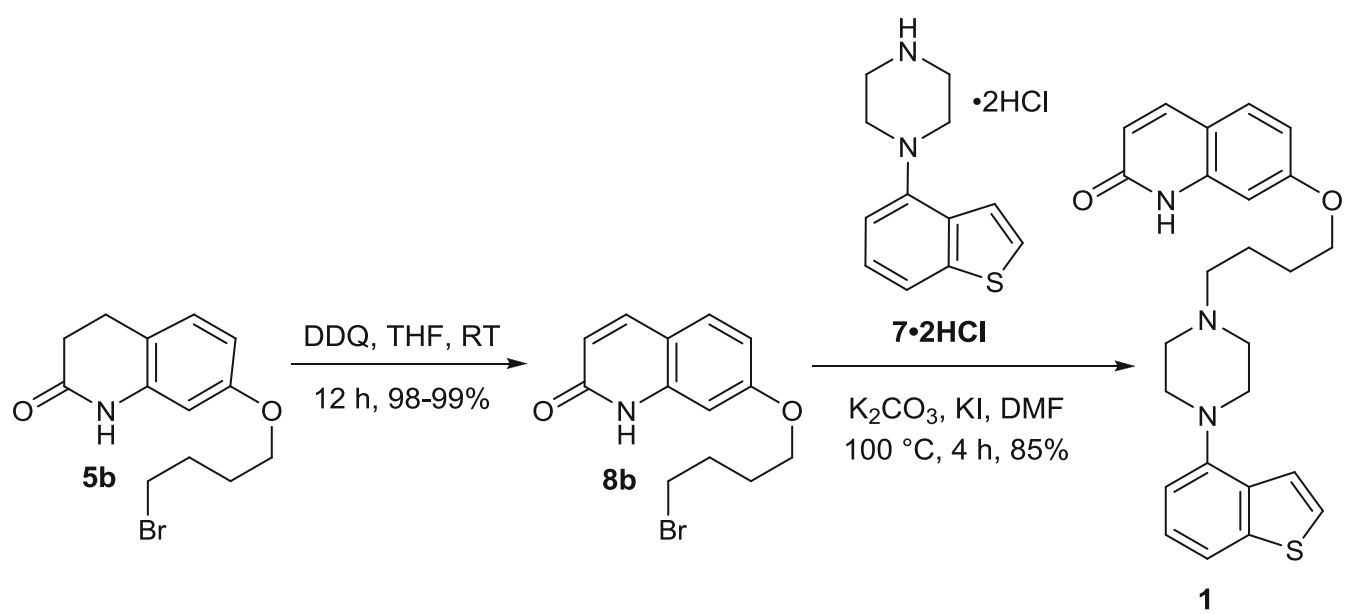

Scheme 7. Preparation of $\mathbf{8 b}$ and the end-game C-N bond formation to afford $\mathbf{1}$.

With XPhos as the ligand, other well-known palladium catalysts, namely $\mathrm{Pd}\left(\mathrm{PPh}_{3}\right)_{4}, \mathrm{Pd}\left(\mathrm{PPh}_{3}\right)_{2} \mathrm{Cl}_{2}$ and $\mathrm{Pd}_{2}(\mathrm{dba})_{3} \cdot \mathrm{CHCl}_{3}$, were screened (Table 1, Entries 5-7) to evaluate their efficiency vis-à-vis $\mathrm{Pd}(\mathrm{OAc})_{2}$ (Table 1 , Entry 4) in promoting the Buchwald-Hartwig coupling between 1-Boc-piperazine and 23. Thus, a combination of $\mathrm{Pd}_{2}(\mathrm{dba})_{3} \cdot \mathrm{CHCl}_{3}$ and X-Phos (Table 1, Entry

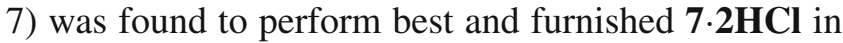
$78 \%$ isolated yield. Indeed, when employed with other phosphine ligands [viz., (o-tol $)_{3} \mathrm{P}$ (Table 1, Entry 8) and CyJohnPhos (Table 1, Entry 9)], $\mathrm{Pd}_{2}(\mathrm{dba})_{3} \cdot \mathrm{CHCl}_{3}$ fared worse in comparison so that $\mathrm{Pd}_{2}(\mathrm{dba})_{3} \cdot \mathrm{CHCl}_{3}$ and $\mathrm{X}$-Phos were eventually chosen as the catalyst/ligand combination in our first attempt to effect the desired Buchwald-Hartwig amination of $\mathbf{2 3}$ on a gram scale. Gratifyingly, coupling of the triflate 23 with 1-Bocpiperazine in presence of $10 \mathrm{~mol} \% \mathrm{Pd}_{2}(\mathrm{dba})_{3} \cdot \mathrm{CHCl}_{3}$ and $15 \mathrm{~mol} \%$ XPhos was uneventful even on a $2 \mathrm{~g}$ scale (Table 1, Entry 10), and the reaction went to near completion within $8 \mathrm{~h}$ at $100{ }^{\circ} \mathrm{C}$ to cleanly afford 17. In fact, absence of any major side reactions in this coupling step rendered a complete purification of the $\mathrm{N}$-Boc derivative $\mathbf{1 7}$ prior to its conversion into 7.2HCl entirely unnecessary. The crude reaction mixture, obtained from the Buchwald-Hartwig amination of $\mathbf{2 3}$, needed to be passed through a short silica gel column merely to remove inorganic matter and unreacted 1-Boc-piperazine. The partially purified product $\mathbf{1 7}$ was thereafter subjected to $N$-Boc deprotection with dilute $\mathrm{HCl}$, and the desired intermediate $\mathbf{7 \cdot 2} \mathbf{H C l}$ isolated with $>99 \%$ purity simply by extracting out the non-basic impurities from the acidic milieu with dichloromethane.

Having established the proof-of-concept for a novel synthesis of $\mathbf{7 \cdot 2} \mathbf{H C l}$ from $\mathbf{2 3}$, we were goaded to investigate if the Buchwald-Hartwig coupling could be made more economical by lowering the required loading of $\mathrm{Pd}_{2}(\mathrm{dba})_{3} \cdot \mathrm{CHCl}_{3}$ and XPhos. After a few trials, the desired conversion of $\mathbf{2 3}$ into $\mathbf{1 7}$ could indeed be achieved with not only $3 \mathrm{~mol} \% \mathrm{Pd}_{2}(\mathrm{dba})_{3} \cdot \mathrm{CHCl}_{3}$ and $6 \mathrm{~mol} \%$ XPhos (Table 1, Entry 11), but also $1 \mathrm{~mol} \%$ $\mathrm{Pd}_{2}(\mathrm{dba})_{3} \cdot \mathrm{CHCl}_{3}$ and $3 \mathrm{~mol} \%$ XPhos (Table 1, Entry 12). It was also possible to employ the latter catalyst/ligand loading to effect a complete consumption of 23 even on a $1 \mathrm{~g}$ scale, and obtain $\mathbf{7 \cdot 2} \mathbf{H C l}$ in $87 \%$ yield and $\sim 99 \%$ purity (Table 1, Entry 13). Thus, having accessed one of the two building blocks necessary for the construction of $\mathbf{1}$, the stage was set for us to usher in the second fragment $\mathbf{8 b}$ and converge on the well-known end-game $\mathrm{C}-\mathrm{N}$ bond formation step.

As already alluded to in Section 1.2, it is known that 7-(4-bromobutoxy)quinolinone $\mathbf{8 b}$ can be prepared by DDQ oxidation of the commercially available Aripiprazole precursor $\mathbf{5 b} .{ }^{19}$ With minor modifications to the reported procedure, it was possible for us to carry out this transformation on a $10 \mathrm{~g}$ scale, and conveniently obtain $\mathbf{8 b}$ in near quantitative yield and with HPLC purity $>99 \%$. Thus, with both $\mathbf{7 \cdot 2} \mathbf{H C l}$ and $\mathbf{8 b}$ in hand, the final $\mathrm{N}$-alkylation step was effected in the presence of $\mathrm{K}_{2} \mathrm{CO}_{3}$ and $\mathrm{KI}$ to furnish brexpiprazole 1 (purity 98\%) in $85 \%$ yield (Scheme 7 ).

\section{Conclusions}

To summarize, we have demonstrated a convergent and highly concise synthesis of brexpiprazole 1, wherein the entire framework of the API has been assembled in a few simple steps from three readily available building blocks, viz., 6,7-dihydrobenzo[b]thiophen-4(5H)one 21, 1-Boc-piperazine and the aripiprazole precursor 7-(4-bromobutoxy)-3,4-dihydroquinolinone $\mathbf{5 b}$. Of the two efficacious $\mathrm{C}-\mathrm{N}$ bond formations that constitute 
the crux of our synthetic strategy, the one eventuated by Buchwald-Hartwig coupling between 1-Bocpiperazine and $\mathbf{2 3}$ is particularly noteworthy. Indeed, while the chemistry of benzo[b]thiophen-4-ol 22 is well documented, ${ }^{20}$ any report on the use of its triflate ester 23 to arylate amines is hitherto unknown. Our present endeavor should therefore stimulate further investigations into potential application of $\mathbf{2 3}$ as a source of benzo[b]thiophen-4-yl fragment in Buchwald-Hartwig aminations.

\section{Supplementary Information (SI)}

Scanned copies of ${ }^{1} \mathrm{H}$ and ${ }^{13} \mathrm{C}$ NMR spectra of $\mathbf{1}, \mathbf{7 . 2 H C l}$, $\mathbf{8 b}, \mathbf{1 7}, \mathbf{2 2}$ and $\mathbf{2 3}$ are available at www.ias.ac.in/chemsci.

\section{Acknowledgements}

ASK and SGSK thank Dr. Reddy's Laboratories (DRL) for support through DRILS Postdoctoral Fellowship Program. We thank Dr. S. Vittal and Ms. Shweta Sawner for their preliminary investigations into the synthesis of $\mathbf{7 \cdot 2} \mathbf{H C l}$ and $\mathbf{8 b}$.

\section{References}

1. (a) Das S, Barnwal P, Winston A B, Mondal S and Saha I 2016 Brexpiprazole: so far so good Ther. Adv. Psychopharmacol. 639; (b) Bruijnzeel D and Tandon R 2016 Spotlight on brexpiprazole and its potential in the treatment of schizophrenia and as adjunctive therapy for the treatment of major depression Drug Des. Devel. Ther 10 1641

2. World Health Organization (WHO). Schizophrenia. Fact Sheet No. 397. http://www.who.int/mediacentre/ factsheets/fs397/en/ (reviewed in April 2016; accessed on 19 April 2018)

3. (a) Goff D C 2015 Brexpiprazole: A New Antipsychotic Following in the Footsteps of Aripiprazole Am. J. Psychiatry 172 820; (b) Stahl S M 2016 Mechanism of action of brexpiprazole: comparison with aripiprazole CNS Spectr. 211

4. Jago C In 2015 Drugs to Watch Thomson Reuters Market Insight Report. http://assets.fiercemarkets.net/public/ lifesciences/LS.2015.DrugstoWatch.MarketInsight_ Report\%20FINAL\%203.23.15.pdf (Accessed on 19 April 2018)

5. Kowalski P, Jaśkowska J and Majka Z 2012 Recent Approaches to the Synthesis of Aripiprazole - A New Generation Antypsychotic Drug Mini-Rev. Org. Chem. 9 374

6. Flick A C, Ding H X, Leverett C A, Kyne R E, Liu K K C, Fink S J and O'Donnell C J 2017 Synthetic Approaches to the New Drugs Approved During 2015 J. Med. Chem. 606480

7. Yamashita H, Sato T, Minowa T, Hoshika Y, Toyofuku H, Yamaguchi T, Sota M, Kawano S, Nakamura T, Eto R, Ikebuchi T, Moriyama K and Ito N 2013 Dihydrate of benzothiophene compound or of a salt thereof, and process for producing the same PCT Application WO 2013/162046 A1
8. Yamashita H, Matsubara J, Oshima K, Kuroda H, Ito N, Miyamura S, Shimizu S, Tanaka T, Oshiro Y, Shimada J, Maeda K, Tadori Y, Amada N, Akazawa H, Yamashita J, Mori A, Uwahodo Y, Masumoto T, Kikuchi T, Hashimoto K and Takahashi H 2006 Piperazinesubstituted benzothiophenes for treatment of mental disorders PCT Application WO 2006/112464 A1

9. Shinhama K, Utsumi N, Sota M, Fujieda S and Ogasawara S 2013 Method for producing benzo[b]thiophene compound PCT Application WO 2013/015456 A1

10. Miyake M, Shimizu M, Tsuji K and Ikeda K 2016 Safe and Efficient Decarboxylation Process: A Practical Synthetic Route to 4-Chlorobenzo[b]thiophene Org. Process Res. Dev. 2086

11. Wu C, Chen $\mathrm{W}$, Jiang $\mathrm{D}$, Jiang $\mathrm{X}$ and Shen J 2015 An Improved Synthesis of 4-(1Piperazinyl)benzo[b]thiophene Dihydrochloride Org. Process Res. Dev. 19555

12. (a) Bollikonda $\mathrm{S}$, Mohanarangam $\mathrm{S}$, Jinna $\mathrm{R} \mathrm{R}$, Kandirelli V K K, Makthala L, Sen S, Chaplin D A, Lloyd R C, Mahoney T, Dahanukar V H, Oruganti S and Fox M E 2015 An Enantioselective Formal Synthesis of Montelukast Sodium J. Org. Chem. 80 3891; (b) Nevuluri N R, Rapolu R K, Iqbal J, Kandagatla B, Sen S, Dahanukar V H and Oruganti S 2017 A morpholinefree process amenable convergent synthesis of apixaban: a potent factor Xa inhibitor Monatsh. Chem. 148 1477

13. (a) Harel D, Schepmann D and Wünsch B 2013 New combination of pharmacophoric elements of potent $\sigma_{1}$ ligands: Design, synthesis and $\sigma$ receptor affinity of aminoethyl substituted tetrahydrobenzothiophenes Eur. J. Med. Chem. 69 490; (b) Acheson R M and Cooper M W 1980 The synthesis of thiophenium and of oxazolium salts from diazoketones J. Chem. Soc., Perkin Trans. 1 1185

14. Kawakita Y, Banno H, Ohashi T, Tamura T, Yusa $\mathrm{T}$, Nakayama A, Miki $\mathrm{H}$, Iwata $\mathrm{H}$, Kamiguchi H, Tanaka T, Habuka N, Sogabe S, Ohta Y and Ishikawa T 2012 Design and Synthesis of Pyrrolo[3,2d]pyrimidine Human Epidermal Growth Factor Receptor 2 (HER2)/Epidermal Growth Factor Receptor (EGFR) Dual Inhibitors: Exploration of Novel Back-Pocket Binders J. Med. Chem. 553975

15. Clark P D and Irvine N M 1996 Preparation of 3,4disubstituted benzo $[b]$ thiophenes for use in thia-ergoline synthesis Phosphorus, Sulfur Silicon Relat. Elem. 118 61

16. Oshiro Y, Sato S, Kurahashi N, Tanaka T, Kikuchi T, Tottori K, Uwahodo Y and Nishi T 1998 Novel Antipsychotic Agents with Dopamine Autoreceptor Agonist Properties: Synthesis and Pharmacology of 7-[4-(4-Phenyl-1-piperazinyl)butoxy]-3,4-dihydro2(1H)-quinolinone Derivatives J. Med. Chem. 41 658

17. Kinnick M D, Lin H-S, Martinelli M J, Morin J M and Richett M E 2004 sPLA2 inhibitors U.S. Patent 6713505

18. Drewry D T and Scrowston R M 1969 Bromination and Vilsmeier-Haack formylation of 6,7-dihydrobenzo[b]thiophen-4(5H)-one J. Chem. Soc. C 2750

19. Poorna Chander T, Satyanarayana B, Ramesh Kumar N, Pratap Reddy P and Anjaneyulu Y 2007 Synthesis and 
Characterization of Related Compounds of Aripiprazole, an Antipsychotic Drug Substance Synth. Commun. 37 4337
20. Mukherjee C and De A 2001 Certain aspects of the chemistry of hydroxybenzo $[b]$ thiophene J. Indian Inst. Sci. 81 417 